\title{
Bis(3-phenylpropylammonium) dichromate (VI): Synthesis, crystal structure and spectroscopy studies
}

\section{SoniaTrabelsi, Thierry Roisnel, Houda Marouani ${ }^{\star}$}

Laboratoire de Chimie des Matériaux, Faculté des Sciences de Bizerte, 7021 Zarzouna Bizerte, Université de Carthage, Tunisie

\section{sonia.trabelsi1@gmail.com}

Centre de Diffractométrie X, UMR6226 CNRS, Unité Sciences Chimiques de Rennes, Université de Rennes I, 263 Avenue du General Leclerc, 35042 Rennes, France

\section{thierry.roisnel@univ-rennes1.fr}

Laboratoire de Chimie des Matériaux, Faculté des Sciences de Bizerte, 7021 Zarzouna Bizerte, Université de Carthage, Tunisie

\section{houda_marouani@voila.fr}

\section{ABSTRACT}

The structure of bis(3-Phenylpropylammonium) dichromate(VI) was determined from X-ray diffraction data. The compound crystallizes in the monoclinic system (space group $\left.P 2_{1} / c\right)$ with the lattice parameters: $a=7.9379(2) \AA, b=36.2439(16) \AA$, $c=7.5753(3) \AA ; \beta=96.069(2) ; V=2167.20(14) \AA^{3}$ and $Z=4$. The structure was solved from 4959 independent reflections with $\mathrm{R}=0.043$ and $\mathrm{Rw}=0.105$. The structure consists of discrete dichromate anions $\left(\mathrm{Cr}_{2} \mathrm{O}_{7}{ }^{2-}\right)$ with eclipsed conformation stacked in layers parallel to $(a, c)$ plane at $y=0$ and $1 / 2$. These anions are linked via the 3-phenylpropylammonium cations by $\mathrm{N}-\mathrm{H}$... $\mathrm{O}$ and $\mathrm{C}-\mathrm{H}$... $\mathrm{O}$ hydrogen bonds, forming a two-dimensional supramolecular network. Crystal structure and spectroscopic studies are reported for the bis(3-phenylpropylammonium) dichromate(VI).

\section{Indexing terms/Keywords}

Organic-inorganic hybrid material; dichromate (VI); Single crystal X-ray; IR Spectroscopy; UV-visible Spectroscopy.

\section{Council for Innovative Research}

Peer Review Research Publishing System

Journal: Journal of Advances in Chemistry

Vol. 11, No. 1

editorjaconline@gmail.com

www.cirjac.com 


\section{INTRODUCTION}

The design and synthesis of new solid materials with controlled structure are a current challenge in solid state chemistry. Recent a large number of dichromates of organic bases have been prepared and used as reagents in mild selective oxidation processes of organic substrates [1,2], so as to exhibit some interesting crystal structure and some special properties in several areas, such as nonlinear optical (NLO), catalysis and biology [3, 4].

Knowledge of the crystal structures and mechanisms of these associations in hybrid organic-inorganic materials can help to understand their physic-chemical properties. In the present contribution, we report the synthesis, characterization by X-ray diffraction, infrared spectroscopy and UV-visible Spectroscopy of a novel organic dichromate, $\left[\mathrm{C}_{9} \mathrm{H}_{14} \mathrm{~N}\right]_{2} \mathrm{Cr}_{2} \mathrm{O}_{7}$.

\section{EXPERIMENTAL SECTION}

\section{II.1.Synthesis}

Single crystals of the title compound were prepared at room temperature by dissolving $\mathrm{CrO}_{3}(0.10 \mathrm{~g}, 1 \mathrm{mmol})$ and 3-phenylpropylamine (Hydrocinnamylamine, $0.13 \mathrm{~g}, 1 \mathrm{mmol}$ ) in distilled water $(20 \mathrm{~mL})$. The resulting aqueous solution was stirred during $2 \mathrm{~h}$, filtered and then evaporated slowly at room temperature $(298 \mathrm{~K})$ until the formation of orange prismatic single crystals.

\section{II.2. Single crystal structure determination}

The intensity data were collected at room temperature using an APEXII Bruker-AXS [5] diffactometer with Mo Ka radiation $(0.71073 \AA$ ). The structure was solved by direct methods using the SIR97 program [6] and refined by full-matrix least-squares using SHELX programs [7] in the WinGX package [8]. A semi-empirical absorption correction multi-scan [5] was then applied. All non hydrogen atoms were refined anisotropically by full matrix least-square method. The $\mathrm{H}$ atoms were treated as riding, with $\mathrm{C}-\mathrm{H}=0.97 \AA, \mathrm{N}-\mathrm{H}=0.89 \AA$. The parameters used for the X-ray data collection as well as the strategy for the crystal structure determination and its final results are reported in Table 1 . The final atomic coordinates obtained from the single crystal refinement with $U_{\text {eq }}$ are given in Table 2. Interatomic distances and bond angles schemes are listed in Table 3. Hydrogen bonding parameters are reported in Table 4.

Crystallographic data for the structural analysis have been deposited with the Cambridge Crystallographic Data Centre, CCDC No 1038891. These data can be obtained free of charge via http://www.ccdc.cam.ac.uk/conts/retrieving.html, or from the CCDC, 12 Union Road, Cambridge, CB2 1EZ, UK: fax: (+44) 01223-336-033; e-mail: deposit@ccdc.cam.ac.

Table 1. Crystal data and summary of intensity data collection and structure refinement of $\left[\mathrm{C}_{9} \mathrm{H}_{14} \mathrm{~N}_{2} \mathrm{Cr}_{2} \mathrm{O}_{7}\right.$

\section{Crystal data}

Empirical formula

Formula weight $(\mathrm{g} / \mathrm{mol})$

Crystal system, Space group

$$
\mathrm{a}(\AA)
$$

$\mathrm{b}(\AA)$

$c(\AA)$

$\alpha\left({ }^{\circ}\right)$

$\beta\left({ }^{\circ}\right)$

$\gamma\left({ }^{\circ}\right)$

$2\left(\mathrm{C}_{9} \mathrm{H}_{14} \mathrm{~N}\right) \mathrm{Cr}_{2} \mathrm{O}_{7}$

488.42

monoclinic, $\mathrm{P} 2_{1} / \mathrm{c}$

$7.9379(2)$

$36.2439(16)$

7.5753(3)

90.00

96.069(2)

$\mathrm{V}\left(\AA^{3}\right)$

90.00

2167.20(14)

Z

4

$\mathrm{F}(000)$

1016

$D_{\text {calc }}\left(\mathrm{g} \mathrm{cm}^{-3}\right)$

1.497

$\mu\left(\mathrm{mm}^{-1}\right)$

1.04

Crystal size (mm)

$0.52 \times 0.25 \times 0.09$

Crystal habit

orange, prism 


\section{Data collection}

Diffractometer

Radiation type, $\lambda(\AA)$

$T(\mathrm{~K})$

$\theta$ Range $\left(^{\circ}\right)$

Indexes range

Absorption correction

$\mathrm{T}_{\min } / \mathrm{T}_{\max }$

Measured reflections

Independent reflections

Observed refl. $(I>2 \sigma(I))$

$R_{\text {int }}$

\section{Refinement}

Data/restraints/parameters

$\left.\mathrm{R}\left(\mathrm{F}_{0}{ }^{2}\right)>2 \sigma\left(\mathrm{F}_{0}{ }^{2}\right)\right]$

$\mathrm{GooF}=\mathrm{S}$
APEXII, Bruker-AXS

MoKa, 0.71073

150

$2.6-27.4$

$-8 \leq \mathrm{h} \leq 9$

$-42 \leq \mathrm{k} \leq 47$

$-10 \leq \mathrm{I} \leq 10$

multi-scan

$0.722 / 0.910$

18139

4959

4147

0.053

$4959 / 0 / 264$

$R=0.043$

$R w=0.105$

1.06

Table 2 Fractional atomic coordinates and isotropic or equivalent isotropic displacement parameters $\left(\AA^{2}\right)$ for $\left[\mathrm{C}_{9} \mathrm{H}_{14} \mathrm{~N}_{2} \mathrm{Cr}_{2} \mathrm{O}_{7}\right.$.

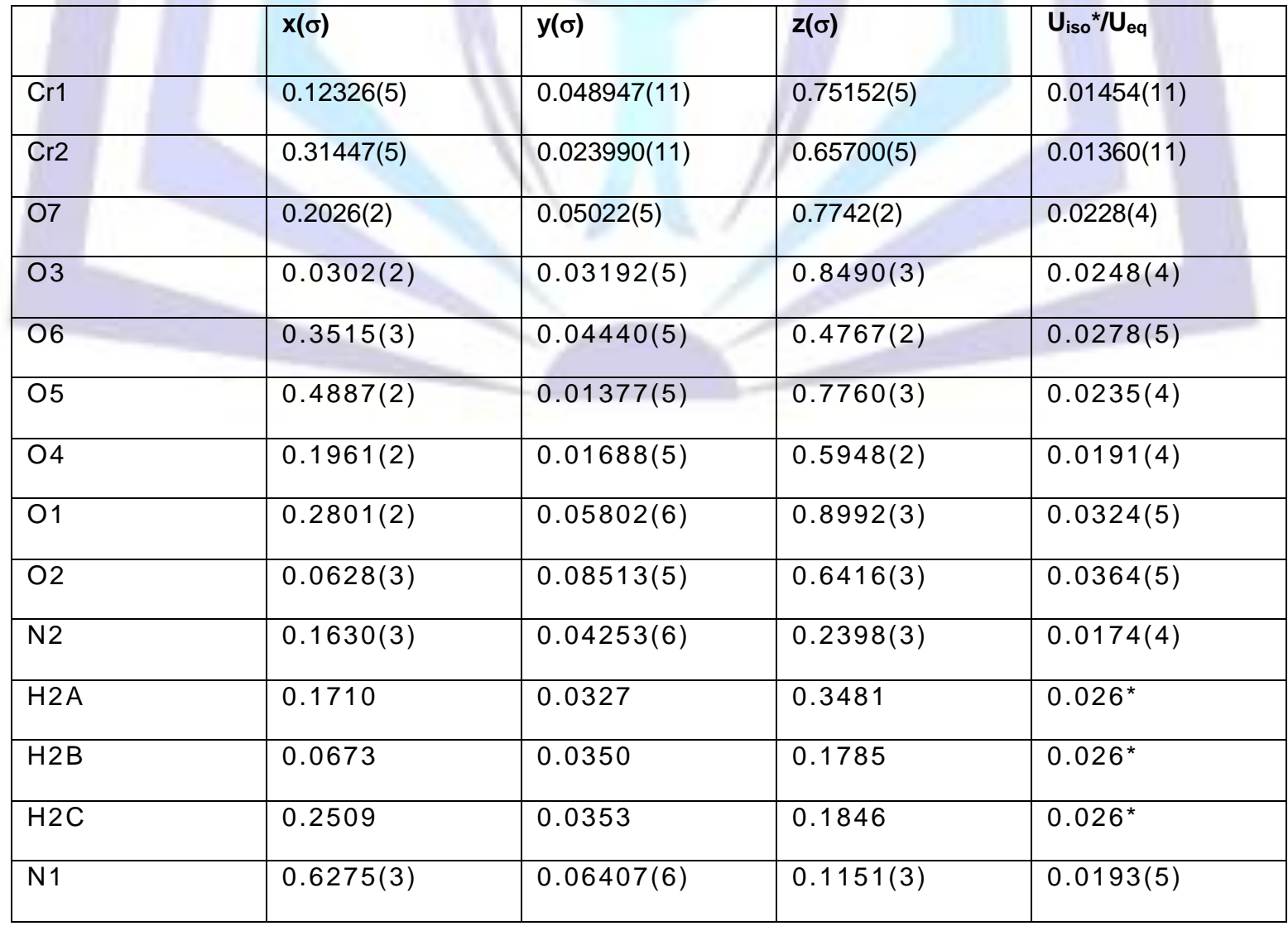




\begin{tabular}{|c|c|c|c|c|}
\hline $\mathrm{H} 1 \mathrm{~A}$ & 0.6951 & 0.0565 & 0.0208 & $0.029^{*}$ \\
\hline $\mathrm{H} 1 \mathrm{~B}$ & 0.5245 & 0.0546 & 0.1113 & $0.029^{*}$ \\
\hline $\mathrm{H} 1 \mathrm{C}$ & 0.6691 & 0.0566 & 0.2136 & $0.029^{*}$ \\
\hline C11 & $0.3349(3)$ & $0.09772(7)$ & $0.3277(3)$ & $0.0174(5)$ \\
\hline $\mathrm{H} 11 \mathrm{~A}$ & 0.3697 & 0.0854 & 0.4394 & $0.021^{*}$ \\
\hline $\mathrm{H} 11 \mathrm{~B}$ & 0.4171 & 0.0919 & 0.2458 & $0.021^{*}$ \\
\hline C13 & $0.5032(3)$ & $0.15756(7)$ & $0.3983(3)$ & $0.0203(5)$ \\
\hline C10 & $0.1627(3)$ & $0.08370(7)$ & $0.2537(3)$ & $0.0174(5)$ \\
\hline $\mathrm{H} 10 \mathrm{~A}$ & 0.1322 & 0.0943 & 0.1371 & $0.021^{*}$ \\
\hline $\mathrm{H} 10 \mathrm{~B}$ & 0.0787 & 0.0914 & 0.3303 & $0.021^{*}$ \\
\hline $\mathrm{C} 1$ & $0.6171(3)$ & $0.10520(7)$ & $0.1143(4)$ & $0.0205(5)$ \\
\hline $\mathrm{H} 1 \mathrm{D}$ & 0.5606 & 0.1137 & 0.2267 & $0.025^{*}$ \\
\hline $\mathrm{H} 1 \mathrm{E}$ & 0.5509 & 0.1132 & 0.0207 & $0.025^{*}$ \\
\hline C3 & $0.7901(3)$ & $0.16394(7)$ & $0.0822(4)$ & $0.0243(6)$ \\
\hline $\mathrm{H} 3 \mathrm{~A}$ & 0.7264 & 0.1722 & 0.0129 & $0.029^{*}$ \\
\hline $\mathrm{H} 3 \mathrm{~A}$ & 0.7264 & 0.1722 & 0.0129 & $0.029^{*}$ \\
\hline $\mathrm{H} 3 \mathrm{~B}$ & 0.7321 & 0.1728 & 0.1932 & $0.029^{*}$ \\
\hline $\mathrm{C} 2$ & $0.7920(3)$ & $0.12188(7)$ & $0.0851(4)$ & $0.0234(6)$ \\
\hline $\mathrm{H} 2 \mathrm{D}$ & 0.8481 & 0.1130 & 0.0268 & $0.028^{*}$ \\
\hline $\mathrm{H} 2 \mathrm{E}$ & 0.8574 & 0.1136 & 0.1788 & $0.028^{*}$ \\
\hline $\mathrm{C} 4$ & $0.9654(3)$ & $0.18082(7)$ & $0.0563(4)$ & $0.0232(6)$ \\
\hline C14 & $0.6564(3)$ & $0.13852(7)$ & $0.4077(4)$ & $0.0220(6)$ \\
\hline $\mathrm{H} 14$ & 0.6561 & 0.1131 & 0.3924 & $0.026^{*}$ \\
\hline C12 & $0.3313(3)$ & $0.13934(7)$ & $0.3574(4)$ & $0.0242(6)$ \\
\hline $\mathrm{H} 12 \mathrm{~A}$ & 0.2645 & 0.1443 & 0.4548 & $0.029^{*}$ \\
\hline $\mathrm{H} 12 \mathrm{~B}$ & 0.2740 & 0.1508 & 0.2520 & $0.029^{*}$ \\
\hline C15 & $0.8096(3)$ & $0.15720(8)$ & $0.4397(4)$ & $0.0272(6)$ \\
\hline $\mathrm{H} 15$ & 0.9108 & 0.1441 & 0.4461 & $0.033^{*}$ \\
\hline C17 & $0.6612(4)$ & $0.21414(8)$ & $0.4546(5)$ & $0.0377(8)$ \\
\hline $\mathrm{H} 17$ & 0.6622 & 0.2396 & 0.4706 & $0.045^{\star}$ \\
\hline C9 & $0.9996(4)$ & $0.21069(8)$ & $0.0579(4)$ & $0.0314(7)$ \\
\hline $\mathrm{H} 9$ & 0.9139 & 0.2202 & 0.1192 & $0.038^{*}$ \\
\hline $\mathrm{C} 6$ & $1.2574(4)$ & $0.18343(8)$ & $0.1207(4)$ & $0.0338(7)$ \\
\hline $\mathrm{H} 6$ & 1.3440 & 0.1742 & 0.1817 & $0.041^{*}$ \\
\hline $\mathrm{C} 8$ & $1.1599(5)$ & $0.22642(8)$ & $0.0812(5)$ & $0.0402(9)$ \\
\hline $\mathrm{H} 8$ & 1.1799 & 0.2464 & 0.1573 & $0.048^{*}$ \\
\hline $\mathrm{C5}$ & $1.0975(4$ & $0.16747(8)$ & $0.1459(4)$ & $0.0278(6)$ \\
\hline
\end{tabular}




\begin{tabular}{|l|l|l|l|l|}
\hline H5 & 1.0784 & 0.1476 & 0.2233 & $0.033^{*}$ \\
\hline C18 & $0.5087(4)$ & $0.19569(8)$ & $0.4238(4)$ & $0.0325(7)$ \\
\hline H18 & 0.4079 & 0.2089 & 0.4200 & $0.039^{*}$ \\
\hline C7 & $1.2892(4)$ & $0.21282(9)$ & $0.0064(5)$ & $0.0376(8)$ \\
\hline H7 & 1.3967 & 0.2233 & 0.0110 & $0.045^{*}$ \\
\hline C16 & $0.8129(4)$ & $0.19489(8)$ & $0.4619(4)$ & $0.0301(7)$ \\
\hline H16 & 0.9157 & 0.2073 & 0.4815 & $0.036^{*}$ \\
\hline
\end{tabular}

\section{II.3. Physical measurements}

IR spectrum was recorded using $\mathrm{KBr}$ pellets in the range of $4000-400 \mathrm{~cm}^{-1}$ on a Nicolet IR200 FT-IR Spectrometer at ambient temperature.

UV-Visible spectra were recorded on a Perkin Elmer Lambda 19 spectrophotometer in the 200 - $800 \mathrm{~nm}$ range.

\section{RESULTS AND DISCUSSION}

\section{III.1 Structure Description}

The asymmetric unit of the title compound is composed of two independent monoprotonated 3phenylpropylammonium cations and one dichromate dianion (Fig.1).

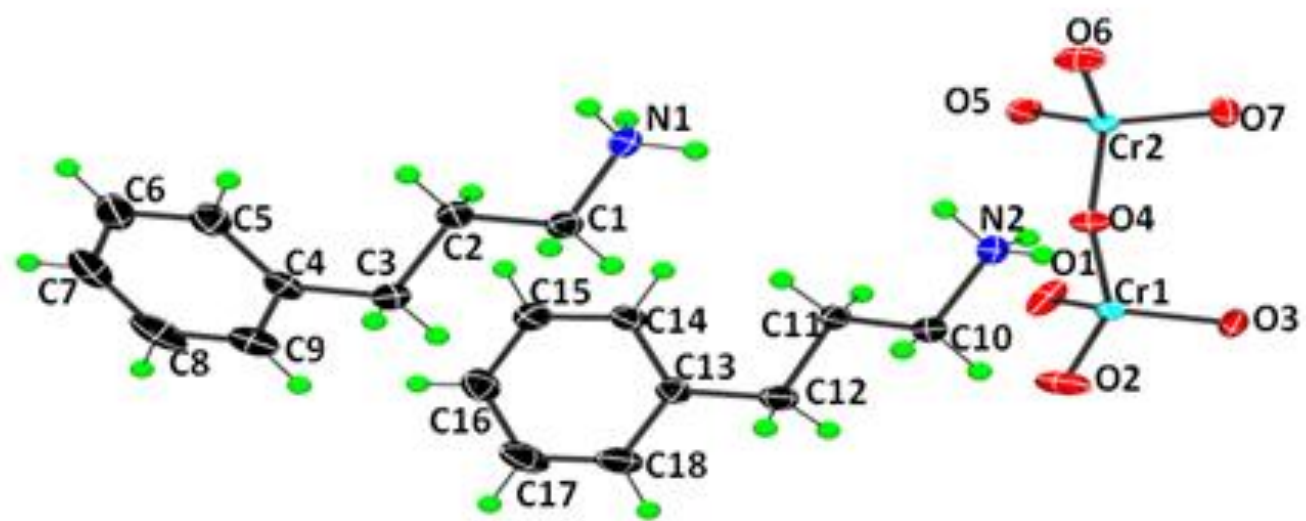

Figure 1. Asymmetric unit of $\left[\mathrm{C}_{9} \mathrm{H}_{14} \mathrm{~N}_{2} \mathrm{Cr}_{2} \mathrm{O}_{7}\right.$ with the atom numbering scheme and thermal ellipsoids at $50 \%$ probability and except for $\mathrm{H}$-atoms, which are represented by spheres of arbitrary radii.

The structure of this compound can be described as a two-dimensional arrangement of inorganic and organic entities parallel to the plane $(010)$ at $y=0$ and $1 / 2$. Dichromate anions and 3 -phenylpropylammonium cations are linked together by mean of hydrogen bonds types $\mathrm{N}-\mathrm{H} \ldots \mathrm{O}$ and $\mathrm{C}-\mathrm{H} \ldots \mathrm{O}$ (Fig.2). 


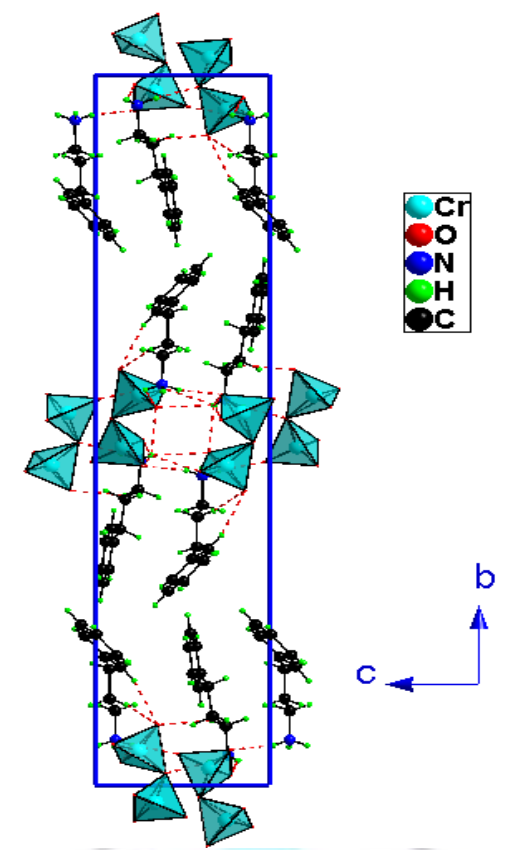

Figure 2. Projection of the crystal structure of $\left[\mathrm{C}_{9} \mathrm{H}_{14} \mathrm{~N}\right]_{2} \mathrm{Cr}_{2} \mathrm{O}_{7}$ along the a-axis. The dotted lines indicate hydrogen bonds.

Dichromate anion is formed by two tetrahedral $\mathrm{CrO}_{4}$ groups joined through shared $\mathrm{O}$ atom, with eclipsed conformation. Interatomic bond lengths and angles of the dichromate anions spread respectively within the ranges [1.5994

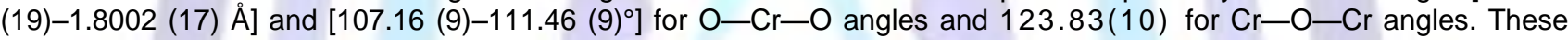
geometrical features have also been noticed in others related crystal structures $[9,10]$.

Table 3 Principal intermolecular distances $(\AA)$ and angles $\left(^{\circ}\right)$ in $\left[\mathrm{C}_{9} \mathrm{H}_{14} \mathrm{~N}\right]_{2} \mathrm{Cr}_{2} \mathrm{O}_{7}$

\begin{tabular}{|c|c|c|c|}
\hline $\mathrm{Cr} 1-\mathrm{O} 2$ & $1.5994(19)$ & C13-C12 & $1.518(3)$ \\
\hline $\mathrm{Cr} 1-\mathrm{O} 3$ & $1.6125(18)$ & $\mathrm{C} 1-\mathrm{C} 2$ & $1.509(3)$ \\
\hline $\mathrm{Cr} 1-\mathrm{O} 1$ & $1.6171(19)$ & $\mathrm{C} 3-\mathrm{C} 4$ & $1.514(4)$ \\
\hline $\mathrm{Cr} 1-\mathrm{O} 4$ & $1.8002(17)$ & $\mathrm{C} 3-\mathrm{C} 2$ & $1.525(4)$ \\
\hline $\mathrm{Cr} 2-\mathrm{O} 6$ & $1.6074(19)$ & $\mathrm{C} 4-\mathrm{C} 9$ & $1.394(4)$ \\
\hline $\mathrm{Cr} 2-\mathrm{O} 5$ & $1.6121(17)$ & $\mathrm{C} 4-\mathrm{C} 5$ & $1.395(4)$ \\
\hline $\mathrm{Cr} 2-\mathrm{O} 7$ & $1.6272(18)$ & C14-C15 & $1.391(4)$ \\
\hline $\mathrm{Cr} 2-\mathrm{O} 4$ & $1.7902(17$ & C15-C16 & $1.377(4)$ \\
\hline $\mathrm{N} 2-\mathrm{C} 10$ & $1.496(3)$ & C17-C18 & $1.381(4)$ \\
\hline $\mathrm{N} 1-\mathrm{C} 1$ & $1.493(3)$ & C17-C16 & $1.388(4)$ \\
\hline C11-C10 & $1.510(3)$ & $\mathrm{C} 9-\mathrm{C} 8$ & $1.388(5)$ \\
\hline C11-C12 & $1.526(3)$ & $\mathrm{C} 6-\mathrm{C} 7$ & $1.379(5)$ \\
\hline C13-C14 & $1.393(4)$ & $\mathrm{C} 6-\mathrm{C} 5$ & $1.389(4)$ \\
\hline C13-C18 & $1.395(4)$ & $\mathrm{C} 8-\mathrm{C} 7$ & $1.371(5)$ \\
\hline $\mathrm{O} 2-\mathrm{Cr} 1-\mathrm{O} 3$ & $110.65(11)$ & $\mathrm{N} 2-\mathrm{C} 10-\mathrm{C} 11$ & $110.70(19)$ \\
\hline $\mathrm{O} 2-\mathrm{Cr} 1-\mathrm{O} 1$ & $111.10(12)$ & $\mathrm{N} 1-\mathrm{C} 1-\mathrm{C} 2$ & $110.5(2)$ \\
\hline $\mathrm{O} 3-\mathrm{Cr} 1-\mathrm{O} 1$ & $108.93(10)$ & $\mathrm{C} 4-\mathrm{C} 3-\mathrm{C} 2$ & $113.3(2)$ \\
\hline $\mathrm{O} 2-\mathrm{Cr} 1-\mathrm{O} 4$ & $106.60(9)$ & $\mathrm{C} 1-\mathrm{C} 2-\mathrm{C} 3$ & $113.1(2)$ \\
\hline $\mathrm{O} 3-\mathrm{Cr} 1-\mathrm{O} 4$ & $111.46(9)$ & $\mathrm{C} 9-\mathrm{C} 4-\mathrm{C} 5$ & $117.7(3)$ \\
\hline
\end{tabular}




\begin{tabular}{|l|l|l|l|}
\hline $\mathrm{O} 1-\mathrm{Cr} 1-\mathrm{O} 4$ & $108.06(9)$ & $\mathrm{C} 9-\mathrm{C} 4-\mathrm{C} 3$ & $120.7(3)$ \\
\hline $\mathrm{O} 6-\mathrm{Cr} 2-\mathrm{O} 5$ & $110.98(10)$ & $\mathrm{C} 5-\mathrm{C} 4-\mathrm{C} 3$ & $121.7(2)$ \\
\hline $\mathrm{O} 6-\mathrm{Cr} 2-\mathrm{O} 7$ & $110.73(10)$ & $\mathrm{C} 15-\mathrm{C} 14-\mathrm{C} 13$ & $120.7(2)$ \\
\hline $\mathrm{O} 5-\mathrm{Cr}-\mathrm{O} 7$ & $108.33(10)$ & $\mathrm{C} 13-\mathrm{C} 12-\mathrm{C} 11$ & $115.5(2)$ \\
\hline $\mathrm{O} 6-\mathrm{Cr}-\mathrm{O} 4$ & $107.16(9)$ & $\mathrm{C} 16-\mathrm{C} 15-\mathrm{C} 14$ & $120.6(3)$ \\
\hline $\mathrm{O} 5-\mathrm{Cr}-\mathrm{O} 4$ & $110.64(9)$ & $\mathrm{C} 18-\mathrm{C} 17-\mathrm{C} 16$ & $120.3(3)$ \\
\hline $\mathrm{O} 7-\mathrm{Cr} 2-\mathrm{O} 4$ & $108.99(9)$ & $\mathrm{C} 8-\mathrm{C} 9-\mathrm{C} 4$ & $120.9(3)$ \\
\hline $\mathrm{Cr} 2-\mathrm{O} 4-\mathrm{Cr} 1$ & $123.83(10)$ & $\mathrm{C} 7-\mathrm{C} 6-\mathrm{C} 5$ & $120.8(3)$ \\
\hline $\mathrm{C} 10-\mathrm{C} 11-\mathrm{C} 12$ & $110.9(2)$ & $\mathrm{C} 7-\mathrm{C} 8-\mathrm{C} 9$ & $120.9(3)$ \\
\hline $\mathrm{C} 14-\mathrm{C} 13-\mathrm{C} 18$ & $118.0(2)$ & $\mathrm{C} 6-\mathrm{C} 5-\mathrm{C} 4$ & $120.8(3)$ \\
\hline $\mathrm{C} 14-\mathrm{C} 13-\mathrm{C} 12$ & $118.3(2)$ & $\mathrm{C} 17-\mathrm{C} 18-\mathrm{C} 13$ & $121.1(3)$ \\
\hline $\mathrm{C} 15-\mathrm{C} 16-\mathrm{C} 17$ & $119.2(3)$ & $\mathrm{C} 8-\mathrm{C} 7-\mathrm{C} 6$ & $119.0(3)$ \\
\hline
\end{tabular}

The voids between the inorganic polyhedra are filled with $\left[\mathrm{C}_{9} \mathrm{H}_{14} \mathrm{~N}\right]^{+}$organic cations. They are hydrogen bonded to $\left[\mathrm{Cr}_{2} \mathrm{O}_{7}\right]^{2-}$ units. In this atomic arrangement two independent 3-phenylpropylammonium cations are present. These cations are organized in opposite direction along the $b$ axis between the inorganic layers (Fig.3). Table 3 presents the main geometrical features of the $\left[\mathrm{C}_{9} \mathrm{H}_{14} \mathrm{~N}\right]^{+}$entities. The $\mathrm{C}-\mathrm{N}$ bond lengths are 1.493(3) and 1.496(3) $\AA$, while the $\mathrm{C}-\mathrm{C}$ bond lengths vary from $1.371(5)$ to $1.525(4) \AA$. The N-C-C and C-C-C angles spread in the range $110.5(2)$ to $120.9(3)^{\circ}$. These values are comparable to those obtained in others compounds associated to the same cation [11, 12]. The aromatic rings are planar with a maximum deviation of $0.0039 \AA$. The propylammonium chain is parallel to the aromatic ring and have alltrans conformation, with the mean deviation of a least-squares plane being less than 0.279 (1) $\AA$.

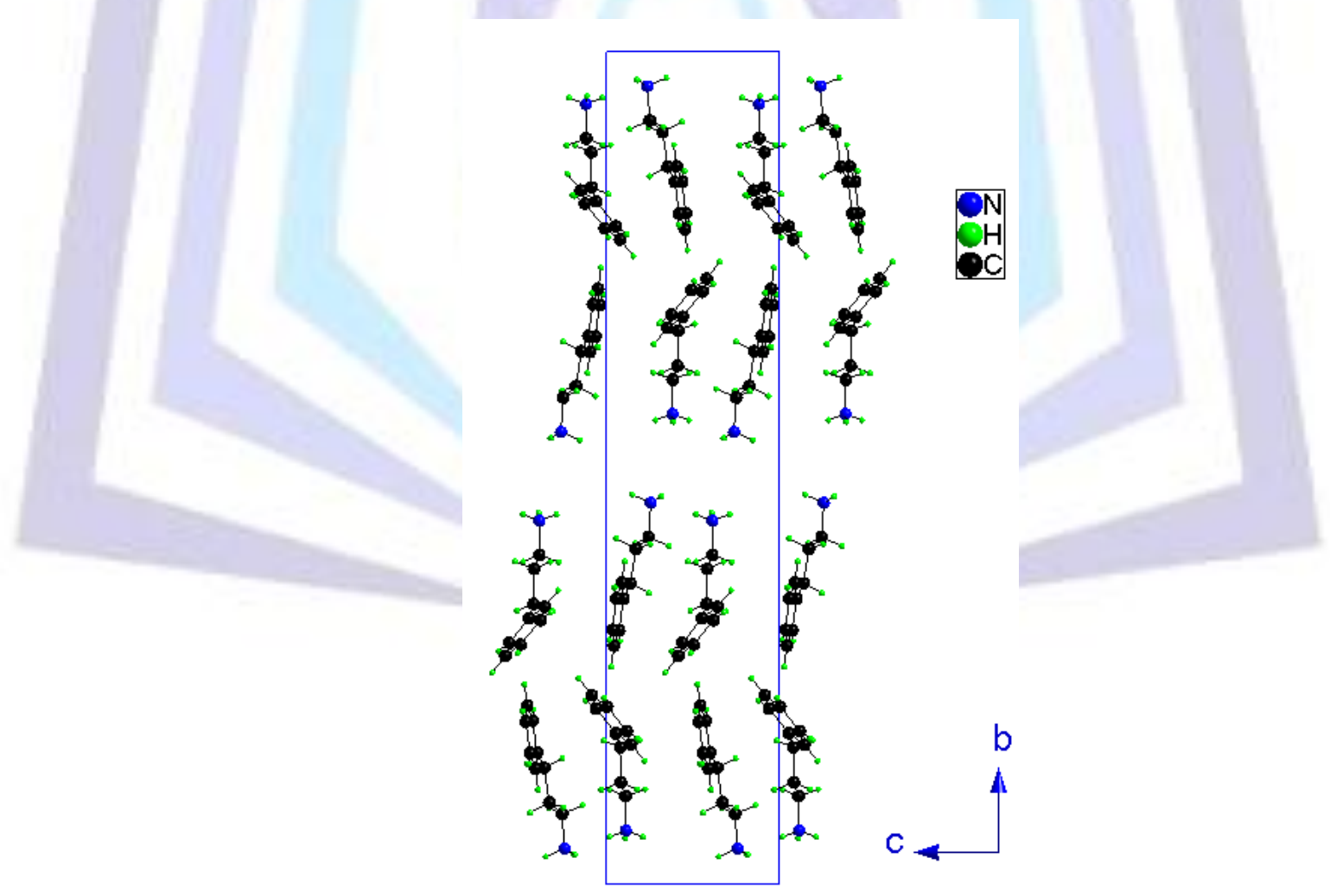

Figure 3. Projection of the organic cations in the crystal structure of $\left[\mathrm{C}_{9} \mathrm{H}_{14} \mathrm{~N}_{2} \mathrm{Cr}_{2} \mathrm{O}_{7}\right.$ along the a-axis

The cations are linked onto the anionic anions, by forming $\mathrm{H}$-bonds with the oxygen atoms of the chromate anions with $\mathrm{N}-\mathrm{H} \cdots \mathrm{O}$ distances in the range $2.780(3)-3.210(3) \AA$ and $\mathrm{C}-\mathrm{H} \cdots \mathrm{O}$ distances in the range $3.124(3)-$ $3.409(3) \AA$ (Table 4). It should be noticed that all the amino hydrogen atoms are involved in $\mathrm{N}-\mathrm{H} \cdots \mathrm{O}$ hydrogen bonding. 
Table 4. Hydrogen bonds $\left(\AA \stackrel{\AA}{\circ}{ }^{\circ}\right)$ for $\left[\mathrm{C}_{9} \mathrm{H}_{14} \mathrm{~N}\right]_{2} \mathrm{Cr}_{2} \mathrm{O}_{7}$

\begin{tabular}{|l|l|l|l|l|}
\hline $\mathbf{D}-\mathbf{H} \cdots \mathbf{A}$ & $\mathbf{D}-\mathbf{H}$ & $\mathbf{H} \cdots \mathbf{A}$ & $\mathbf{D} \cdots \mathbf{A}$ & $\mathbf{D}-\mathbf{H} \cdots \mathbf{A}$ \\
\hline $\mathrm{N} 1-\mathrm{H} 1 \mathrm{~A} \cdots \mathrm{O} 7^{\prime}$ & 0.89 & 1.97 & $2.829(3)$ & 161.8 \\
\hline $\mathrm{N} 1-\mathrm{H} 1 \mathrm{~B} \cdots \mathrm{O} 1^{\prime \prime}$ & 0.89 & 1.95 & $2.780(3)$ & 153.7 \\
\hline $\mathrm{N} 1-\mathrm{H} 1 \mathrm{C} \cdots \mathrm{O} 6^{\prime \prime \prime}$ & 0.89 & 2.03 & $2.853(3)$ & 153.0 \\
\hline $\mathrm{N} 2-\mathrm{H} 2 \mathrm{~A} \cdots \mathrm{O} 4$ & 0.89 & 1.94 & $2.831(3)$ & 173.5 \\
\hline $\mathrm{N} 2-\mathrm{H} 2 \mathrm{~B} \cdots \mathrm{O} 7^{\prime \mathrm{V}}$ & 0.89 & 2.28 & $2.906(3)$ & 127.6 \\
\hline $\mathrm{N} 2-\mathrm{H} 2 \mathrm{~B} \cdots \mathrm{O}^{\prime \prime}$ & 0.89 & 2.54 & $3.210(3)$ & 133.0 \\
\hline $\mathrm{N} 2-\mathrm{H} 2 \mathrm{C} \cdots 5^{\prime}$ & 0.89 & 2.20 & $2.969(3)$ & 144.3 \\
\hline $\mathrm{C} 2-\mathrm{H} 2 \mathrm{E} \cdots \mathrm{O} 2^{\mathrm{v}}$ & 0.97 & 2.46 & $3.409(3)$ & 166.4 \\
\hline $\mathrm{C} 5-\mathrm{H} 5 \cdots \mathrm{O} 2^{\mathrm{v}}$ & 0.93 & 2.48 & $3.388(4)$ & 164.2 \\
\hline $\mathrm{C} 10-\mathrm{H} 10 \mathrm{~B} \cdots \mathrm{O} 2$ & 0.97 & 2.39 & 2.39 & 132.5 \\
\hline
\end{tabular}

(v) $x-1, y, z+1$.

\section{III.2 Infrared Spectroscopy}

We have studied the vibrational properties of our compound using infrared absorption. The infrared spectrum of $\left[\mathrm{C}_{9} \mathrm{H}_{14} \mathrm{~N}_{2} \mathrm{Cr}_{2} \mathrm{O}_{7}\right.$ recorded at room temperature is shown in Figure 4. Although a detailed assignment of all the bands is difficult, the most important attribution mode is realized by comparison with similar compounds [13].

The IR spectra of compound contain the expected four types of frequencies assigned immediately to the $\mathrm{Cr}-\mathrm{O}$ terminal and bridging bonds. This compound exhibit band in $570-500$ and $760-700 \mathrm{~cm}^{-1}$ regions which belong to the symmetric and asymmetric stretching modes of vibration of the $\mathrm{Cr}-\mathrm{O}-\mathrm{Cr}$ fragment. On the other hand, frequencies in 900830 and $940-920 \mathrm{~cm}^{-1}$ regions corresponding to the symmetric and asymmetric $\mathrm{Cr}-\mathrm{O}$ terminal bonds stretching vibrations.

The remaining observed bands in the spectrum can be assigned to $\mathrm{CH}, \mathrm{NH}_{3}{ }^{+}$, and skeletal symmetric and asymmetric stretching and deformation modes. A broad band extending from 3145 to $2954 \mathrm{~cm}^{-1}$ is observed in the IR spectrum. This broad band must be due to the symmetric and asymmetric stretching modes of $\mathrm{NH}_{3}$. Bands in the 1400$1100 \mathrm{~cm}^{-1}$ are attributed to the stretching of the organic groups $v(\mathrm{C}-\mathrm{C}), v(\mathrm{C}-\mathrm{N})$. The shifting of the stretching and bending vibrations of the $\mathrm{NH}_{3}$ group from the free state value confirms the formation of hydrogen bonds of varying strengths in the crystal. Frequencies in the range $1500-1400 \mathrm{~cm}^{-1}$ are attributed to $\delta_{s}(\mathrm{CH})$ and $\delta_{\text {as }}(\mathrm{CH})$. The presence of $\mathrm{C}=\mathrm{C}$ stretching vibrations of the aromatic ring is consistent with the absorption bands at 1600 and $1500 \mathrm{~cm}^{-1}$. 


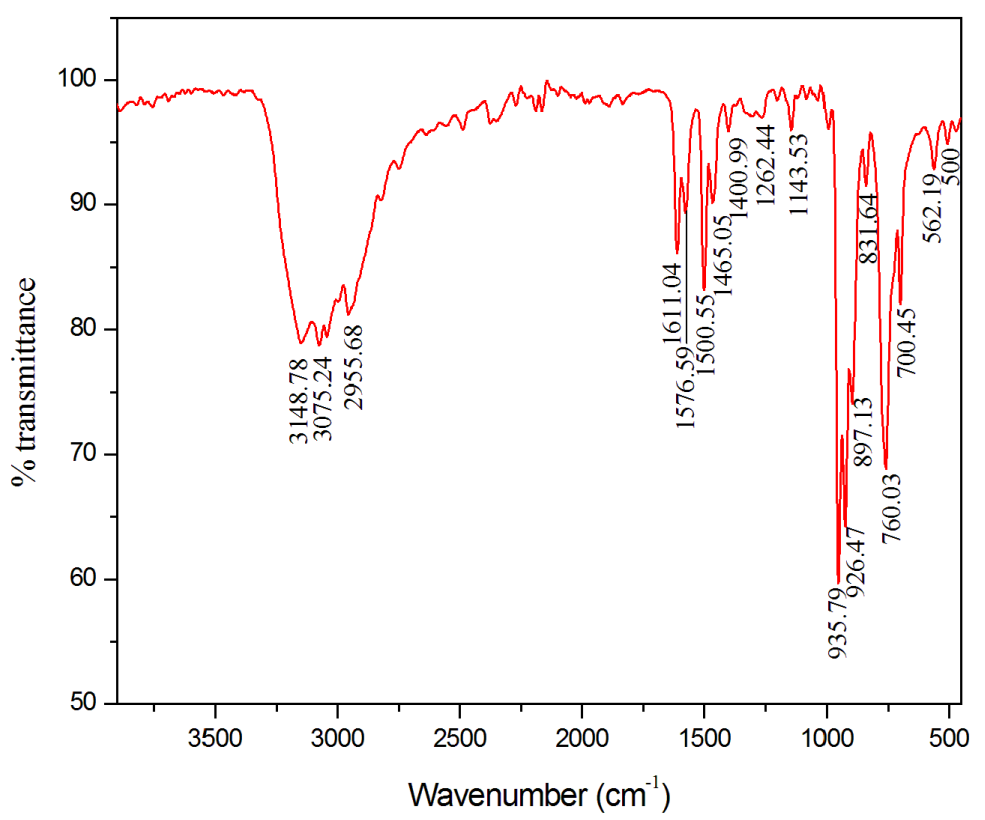

Figure 4. Infrared spectrum of $\left[\mathrm{C}_{9} \mathrm{H}_{14} \mathrm{~N}_{2} \mathrm{Cr}_{2} \mathrm{O}_{7}\right.$

\section{III-3 UV-Visible Absorption and Diffuse Reflectance}

The UV-Visible spectrum of the novel organic dichromate (VI) $\left[\mathrm{C}_{9} \mathrm{H}_{14} \mathrm{~N}_{2} \mathrm{Cr}_{2} \mathrm{O}_{7}\right.$ (Fig. 5) reveals three bands at 297 $\mathrm{nm}, 353 \mathrm{~nm}$ and $442 \mathrm{~nm}$, the medium frequency one being the most intense. This behavior is typical for dichromate [14]. The first and second bands correspond respectively to the $\mathrm{n} \rightarrow \sigma^{*}$ and $\mathrm{n} \rightarrow \pi^{*}$ transitions of the dichromate $\mathrm{Cr}_{2} \mathrm{O}_{7}{ }^{2-}$ anion. In addition, the third band corresponds to the chromium orange color which absorbs in the blue. Moreover the electronic spectrum of the compound provided by using the Tauc model [15], optical band gaps of $2.96 \mathrm{eV}$ as reported in figure 6 , suggesting that the material is a wide-band-gap of dielectric material.

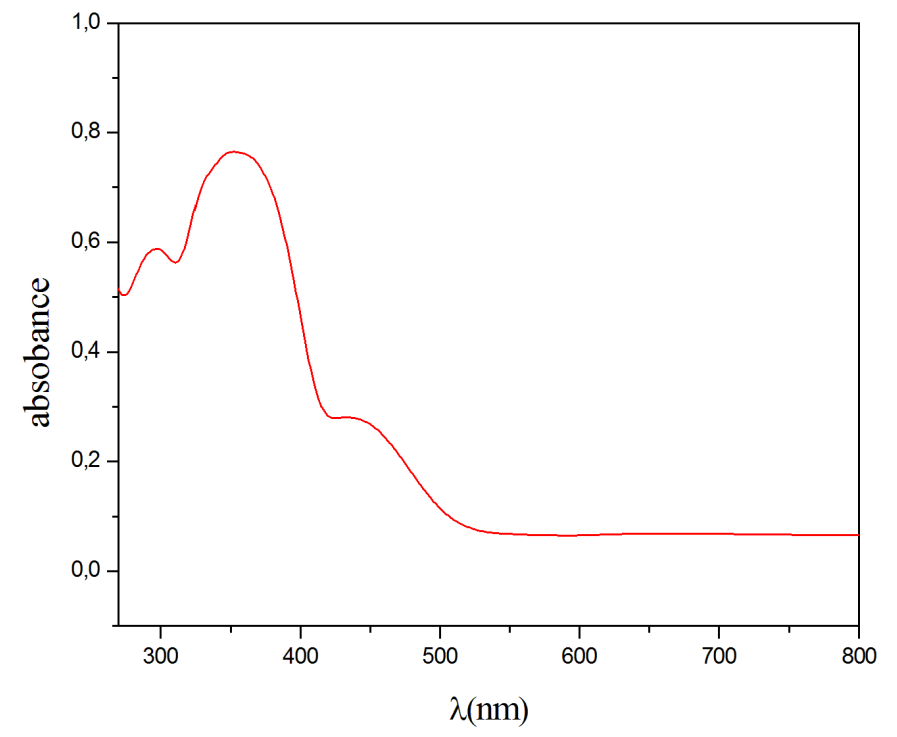

Figure 5. UV-Vis absorption spectrum of $\left[\mathrm{C}_{9} \mathrm{H}_{14} \mathrm{~N}\right]_{2} \mathrm{Cr}_{2} \mathrm{O}_{7}$ 


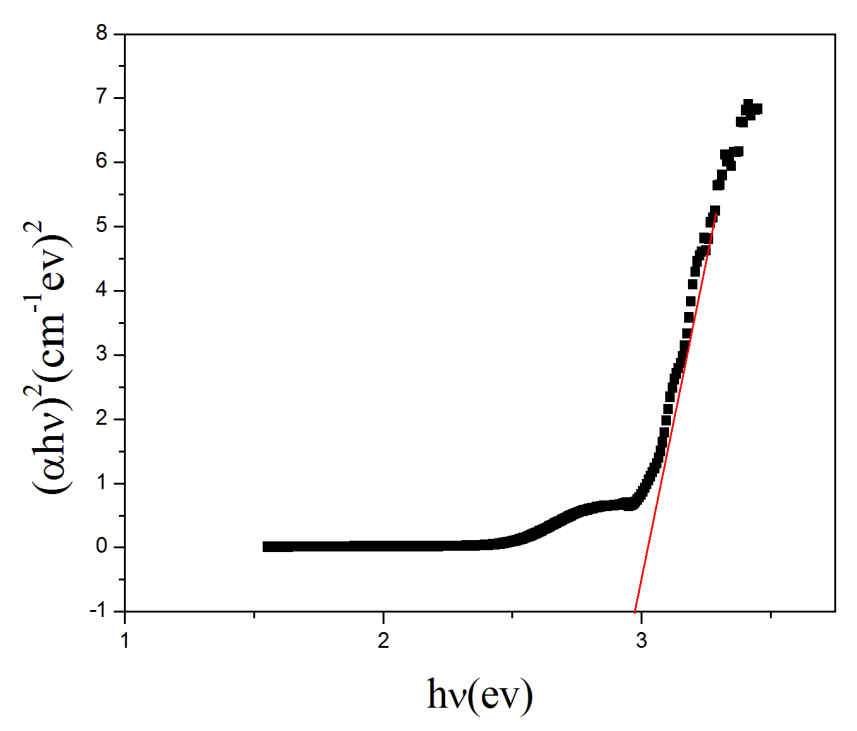

Figure 6. UV diffuse reflectance spectrum for $\left[\mathrm{C}_{9} \mathrm{H}_{14} \mathrm{~N}_{2} \mathrm{Cr}_{2} \mathrm{O}_{7}\right.$

\section{Conclusion}

The compound has been synthesized by slow evaporation at room temperature. The IR spectrum have proved the presence of organic cation, and dichromate $\left(\mathrm{Cr}_{2} \mathrm{O}_{7}\right)$ group. The $\mathrm{X}$-ray structure show that the compound crystallizes in the monoclinic system with $\mathrm{P}_{2} / \mathrm{c}$ space groups and cohesion between the dichromate group and organic cation is provided by $\mathrm{N}-\mathrm{H}$...O and $\mathrm{C}-\mathrm{H}$...O hydrogen-bonding network. The diffuse reflectance data indicate an energy gap 2.96 $\mathrm{eV}$ which is a typical of a dielectric material.

\section{ACKNOWLEDGMENTS}

We would like to thank the Tunisian Ministry of Higher Education and Scientific Research for its financial support.

\section{REFERENCES}

[1] K. Balasubramanian and V. Prathibe, Ind. J. Chem. 25B (1986) 326.

[2] J. Muzart, Chem. Rev. 92 (1992) 113.

[3] G. Le Flem, Eur. J. Solide State Inorg. Chem, 28 (1991).

[4] C. B. Aakerôy, P. B. Hitchcok, B. D. Molyle and K. R. Seddo, J. Chem. Soc. Chem. Commun., (1989) 1856.

[5] Bruker (2006). APEX2, SAINT and SADABS. Bruker AXS Inc., Madison, Wisconsin, USA.

[6] A. Altomare, M. C. Burla, M. Camalli, G. Cascarano, C. Giacovazzo, A. Guagliardi, A. G. G. Moliterni, G. Polidori, R. Spagna, J. Appl. Cryst. 32 (1999) 115-119

[7] G. M. Sheldrick (1997) SHELXS97 and SHELXL97, Program for crystal structure solution and refinement, University of Gottingen, Germany.

[8] L. J. Farrugia, WinGX program for crystallography package. J. Appl. Cryst. 32 (1999) 837.

[9] S. Trabelsi, T. Roisnel, H. Dhaouadi and H. Marouani, Acta Cryst. E70 (2014) m263-m264.

[10] S. Trabelsi, H. Marouani, S. S. Al-Deyab and Mohamed Rzaigui, Acta Cryst. E68 (2012) m1056.

[11] D. G. Billing and A. Lemmerer, Acta Cryst. C62 (2006) m174-176.

[12] A. Lemmerer, Acta Cryst. C64 (2008) 0626-0629.

[13] P. Martin-Zarza, P. Gili, F. V. Rodriguez-Romero, C. Ruiz-Perez and X. Solans, Polyhedron, 14(20-21) (1995) 2907.

[14] B. M. Weckhuysen, A. A. Verberckmoes, A. R. De Baets, and R. A. Schoonheydt, J. Catal. 166 (1997) 160171.

[15] J. Tauc Mater. Res. Bull. 3 (1968) 37-46. 